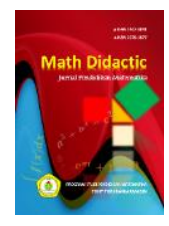

MATH DIDACTIC: JURNAL PENDIDIKAN MATEMATIKA

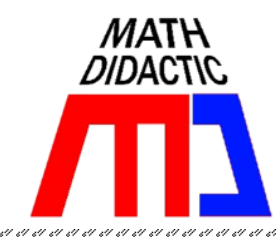

\title{
PENERAPAN MEDIA DAN BUKU AJAR SISWA BERBASIS MEANINGFUL LEARNING PADA MATERI BANGUN DATAR UNTUK MENINGKATKAN BERFIKIR KREATIF SISWA KELAS III SEKOLAH DASAR
}

\author{
THE IMPLEMENTATION OF MEDICAL AND TEACHING BOOKS FOR STUDENTS BASED ON \\ MEANINGFUL LEARNING IN MATTERS AND BUILD FLAT TO IMPROVE CREATIVE CONFIGURATION \\ Normalasarie, Siti Aulia \\ STKIP PGRI Banjarmasin, STKIP PGRI Banjarmasin \\ normala.sari142@gmail.com, sitiaulia@stkipbjm.ac.id
}

\begin{abstract}
Abstrak: Berdasarkan hasil pengamatan dan diskusi dengan guru di SDN Pelambuan 7 Banjarmasin dengan guru kelas III disimpulkan bahwa siswa masih kesulitan dalam mengikuti pembelajaran matematika,khususnya pada materi bangun datar. Bahan ajar yang mereka gunakan selama ini berupa buku pelajaran biasa dan LKS yang jumlahnya terbatas dan bukan buatan guru itu sendiri, sehingga tidak sesuai dengan karakter siswa. Meaningful learning merupakan suatu proses dikaitkan informasi baru dengan konsep-konsep yang relevan yang terdapat dalam struktur kognitif seseorang. Model yang digunakan dalam penelitian ini adalah model Plomp karena memiliki urutan sederhana, sistemis dan jelas dipahami, menurut Plomp (Hobri 2010) ada lima fase dalam mendesain pengembangan ini yaitu (1) Fase investigasi awal (2) Fase desain ( 3) Realisasi/konstruksi (4) Fase evaluasi dan revisi (5) Fase implementasi. Hasil penelitian ini menghasilkan buku ajar siswa. Buku ajar siswa terdiri atas tiga bagian, yaitu bagian pendahuluan, pembahasan dan penutup. Hasil validasi ahli dan praktisi menunjukkan buku ajar siswa yang dikembangkan dinyatakan valid dengan skor rata-rata 3,4. sehingga buku ajar siswa tersebut telah memenuhi kriteria kepraktisan. Keefektifan buku ajar siswa ditentukan dari analisis (1) tes penguasaan materi buku ajar, (2) aktivitas guru dan siswa, dan (3) hasil wawancara dengan siswa. Berdasarkan uji coba yang telah dilaksanakan, diperoleh hasil yaitu sebanyak $85 \%$ mendapat nilai minimal 65, sehingga kriteria ketuntasan secara klasikal telah terpenuhi.
\end{abstract}

Kata Kunci: media, buku ajar, bangun datar

\begin{abstract}
Based on the results of observations and discussions with teachers at Pelambuan 7 Elementary School in Banjarmasin with class III teachers, it was concluded that students were still having difficulties in following mathematics learning, especially on flat-build material. The teaching materials that they use so far are ordinary textbooks and limited number of LKS and are not made by the teacher itself, so that they are not in accordance with the character of students. Meaningful learning is a process of connecting new information with relevant concepts contained in one's cognitive structure. The model used in this study is the Plomp model because it has a simple, systemic and clearly understood sequence, according to Plomp (Hobri 2010) there are five phases in designing this development, namely (1) Initial investigation phase (2) Design phase (3) Realization / construction (4) Evaluation and revision phase (5) Implementation phase. The results of this study produce student textbooks. Student textbooks consist of three parts, namely the introduction, discussion and closing. The results of expert and practitioner validation showed that the developed student textbooks were declared valid with an average score of 3.4. so that the student textbooks have met the practicality criteria. The effectiveness of student textbooks is determined from the analysis of (1) the mastery test of textbook material, (2) the activity of teachers and students, and (3) the results of interviews with students. Based on the trials that have been carried out, the results obtained are as much as $85 \%$ get a minimum score of 65, so that the classical completeness criteria have been met.
\end{abstract}

Keywords: media, textbooks, get up flat

Cara Sitasi: Normalasarie \& Aulia, S. (2018). Penerapan media dan buku ajar siswa berbasis meaningful learning pada materi bangun datar untuk meningkatkan berfikir kreatif siswa kelas III sekolah dasar. Math Didactic: Jurnal Pendidikan Matematika, 4 Edisi Dies Natalis XXXII, 270-276. 
Pembelajaran matematika masih menjadi mata pelajaran yang sulit dan menakutkan. Ada beberapa faktor yang menyebabkan hal tersebut, baik faktor dari guru maupun dari siswanya. Salah satunya dari proses pembelajaran yang diciptakan oleh guru, kurangnya motivasi belajar sehingga mengakibatkan rendahnya minat siswa mempelajari matematika dan tentunya berimbas pada hasil belajar. Untuk meningkatkan motivasi belajar guru dapat menciptakan pembelajaran yang menarik dan menyenangkan, dengan cara menggunakan media atau bahan ajar yang menarik perhatian siswa, sehingga mereka memiliki keinginan untuk kenal lebih jauh tentang matematika dan ingin terus belajar tentang matematika. Beberapa ciri rendahnya motivasi belajar siswa yang menurun yakni siswa kelihatan tidak tertarik dengan pelajaran matematika yang diberikan, dan tugas-tugas berupa soal matematika yang diberikan kadang terkesan dikerjakan seadanya, Peneliti mulai menyusun rencana lebih jauh dalam menyikapi gejala di atas. Hal ini dilakukan untuk mengetahui lebih dalam tentang fakta tersebut. Pada tanggal 24 Januari 2017 peneliti melakukan wawancara terhadap guru pengajar matematika. Peneliti mencoba menindak lanjuti dengan memberikan tes awal berupa soal matematika open-ended yang terkait dengan kompetensi dasar menghitung dan mengenal bangun ruang lainnya. Hasilnya hampir seluruh siswa hanya membuat berupa gambar segitiga. Dari masalah tersebut peneliti memberikan solusi dengan memanfaatkan media yang menarik untuk pembelajaran dapat membangkitkan keinginan dan minat baru. Dalam sebuah penelitian mengatakan Penggunaan media dalam pembelajaran dapat meningkatkan motivasi dan hasil belajar siswa (Normalasarie, 2017, hal. 3).
Kata media berasal dari bahasa latin yang merupakan bentuk jamak dari "Medium" secara harfiah berarti perantara atau pengantar. Association for Education and Communication (AECT), mengartikan media sebagai segala bentuk dan saluran yang dipergunakan untuk proses informasi National Education Association (NEA) mendefinisikan media sebagai media segala benda yang dapat dimanipulasi, dilihat, didengar, dibaca, dibicarakan beserta instrumen yang digunakan untuk kegiatan tersebut.

Menurut Hall-Quest (dalam Tarigan, 1986, hal. 32), buku ajar adalah rekaman pikiran rasional yang disusun untuk maksud dan tujuan instruksional. Large (Tarigan, 1986, hal. 32), mengatakan bahwa buku ajar adalah buku standar/buku setiap khusus studi dan dapat terdiri atas dua tipe, yaitu buku pokok/utama dan buku suplemen/tambahan. Sementara itu, Bacon (dalam Tarigan, 1986, hal. 11) menyatakan bahwa buku ajar adalah buku yang dirancang untuk penggunaan di kelas. Buku ajar akan berpengaruh terhadap kepribadian siswa, walaupun pengaruh itu tidak sama antara siswa satu dengan siswa yang lain. Dengan membaca buku ajar, siswa akan dapat terdorong untuk berpikir dan berbuat yang positif, misalnya memecahkan masalah yang ada dalam buku ajar, melakukan pengamatan yang disarankan dalam buku ajar, atau melakukan pelatihan yang diinstruksikan dalam buku ajar.

Menurut Ausubel (1968, hal. 6), belajar dapat diklasifikasikan ke dalam dua jenis yaitu: belajar hafalan (rote learning) dan belajar bermakna (meaningful learning). Belajar hafalan berhubungan dengan cara informasi atau materi pelajaran disajikan pada siswa, melalui penerimaan atau penemuan. Belajar bermakna (meaningful learning) menyangkut cara-cara bagaimana siswa dapat 
mengaitkan informasi itu pada struktur kognitif yang telah ada. Meaningful Learning merupakan suatu proses dikaitkannya informasi baru dengan konsep-konsep relevan yang terdapat dalam struktur kognitif seseorang (Dahar, 1989, hal. 11). Ausubel mengemukakan bahwa belajar dikatakan bermakna (meaningful) jika informasi yang akan dipelajari siswa disusun sesuai dengan struktur kognitif yang dimiliki siswa sehingga siswa dapat mengaitkan informasi barunya dengan struktur kognitif yang dimilikinya. Dengan meaningful learning ini, ingatan siswa menjadi kuat dan transfer belajar mudah dicapai. Meaningful learning dapat terjadi jika siswa berusaha menghubungkan informasiinformasi baru ke dalam struktur pengetahuan mereka. Siswa dapat mengembangkan skema yang sudah ada atau dapat mengubahnya sehingga dalam belajar siswa mengonstruksi apa yang sedang dipelajari.

\section{Metode Penelitian}

Berisi jenis penelitian, waktu dan tempat penelitian, target/sasaran, subjek penelitian, prosedur, instrumen dan teknik analisis data serta hal-hal lain yang berkait dengan cara penelitiannya.

Penelitian ini merupakan penelitian pengembangan. Dalam penelitian ini yang dikembangkan adalah buku ajar siswa. Buku ajar merupakan salah satu perangkat pembelajaran yang pokok yang dapat diibaratkan jantung dan paru-parunya pembelajaran. Dalam mengembangkan suatu produk, kita dapat menggunakan model pengembangan sebagai acuan. Model pengembangan merupakan dasar untuk mengembangkan produk yang akan dihasilkan (Puslitjaknov, 2008, hal. 8). Model pengembangan yang digunakan dalam penelitian ini adalah model Plomp. Alasan pemilihan model Plomp ini karena memiliki urutan kegiatan yang sederhana, sistematis, dan jelas sehingga mudah untuk dipahami dan diterapkan dalam melakukan pengembangan. Menurut Plomp (Hobri, 2010, hal. 11), model dalam mendesain pengembangan terbagi dalam lima fase, yaitu (1) fase investigasi awal, (2) fase desain, (3) fase realisasi/konstruksi, (4) fase tes, evaluasi dan revisi, (5) fase implementasi.

1. Fase Investigasi Awal

Investigasi awal dilakukan untuk mengidentifikasi kebutuhan guna mengembangkan buku ajar siswa. Kegiatan tersebut meliputi menganalisis standar kompetensi dan kompetensi dasar KTSP SD.

2. Fase Perancangan (Desain)

Berdasarkan fase investigasi awal, selanjutnya dilakukan fase desain (perancangan). Kegiatan yang tercakup dalam fase ini antara lain: mengorganisasikan materi bangun datar kelas III SD menjadi unit-unit yang utuh sesuai standar kompetensi dan kompetensi dasar.

3. Fase Realisasi/Konstruksi

Pada fase ini berisi kegiatan mengembangkan produk. Produk yang dikembangkan (a) buku ajar siswa berbasis meaningful learning pada materi bangun datar untuk kelas III SD.

4. Fase Tes, Evaluasi, \& Revisi

Pada fase ini siswa melaksanakan tes pembelajaran.

5. Fase Implementasi

Fase ini siswa menerapkan bahan ajar yang sudah dikembangkan untuk pembelajaran Rencana Pelaksanaan Pembelajaran (RPP).

Menurut Nieveen (1999, hal. 55) suatu bahan ajar dikatakan baik jika memenuhi 3 kriteria yaitu valid, praktis, dan efektif.

Aspek valid dikaitkan dengan 2 hal yaitu: 
1. Apakah bahan ajar yang dikembangkan didasarkan pada rasional teoritik yang kuat.

2. Apakah terdapat konsisten internal.

Aspek praktis hanya dapat dipenuhi jika:

1. Para ahli dan praktisi menyatakan bahwa apa yang dikembangkan dapat diterapkan.

2. Kenyataan menunjukkan bahwa apa yang dikembangkan tersebut dapat diterapkan

Aspek efektif dapat dipenuhi jika:

1. Ahli dan praktisi berdasarkan pengalamannya menyatakan bahwa bahan ajar tersebut efektif.

2. Secara operasional bahan ajar tersebut memberikan hasil sesuai yang diharapkan.

\section{Hasil Penelitian dan Pembahasan}

\section{Hasil}

Dalam pengembangan buku ajar siswa berbasis meaningful learning pada materi bangun datar kelas III SDN Pelambuan 7 Banjarmasin semester genap tahun pelajaran 2017/2018 ini menggunakan langkah-langkah pengembangan model Plomp (2010, hal. 8), yaitu fase investigasi awal, fase desain, fase konstruksi dan fase tes, evaluasi dan revisi.

Berdasarkan kondisi pembelajaran di atas, maka peneliti akan mengembangkan buku ajar siswa berbasis meaningful learning pada materi bangun datar kelas III, yaitu berupa buku ajar siswa yang komponen kegiatan belajarnya memberikan kesempatan kepada siswa untuk menemukan sendiri konsep materi bangun datar dalam suasana pembelajaran yang menarik sehingga proses belajarnya lebih bermakna dan tidak hanya belajar dengan menghafal.

Data penguasaan materi buku ajar diperoleh berdasarkan tes uji kompetensi dan tes hasil belajar. Tes uji kompetensi yang dimaksud dalam penelitian ini adalah tes yang diberikan pada akhir sub pembahasan materi buku ajar siswa. Dalam buku ajar siswa yang dikembangkan terdapat 2 tes uji kompetensi, yaitu (1) uji kompetensi 1 yang mencakup materi unsur dan sifat-sifat segitiga, persegi dan persegi panjang, dan (2) uji kompetensi 2 yang mencakup materi keliling, luas persegi dan persegi panjang. Sedangkan tes hasil belajar adalah tes tulis berbentuk uraian terdiri dari 9 item soal diselesaikan dengan alokasi waktu 70 menit yang diberikan pada akhir uji coba buku ajar siswa.

Berikut adalah contoh media pembelajaran interaktif yang digunakan uji coba saat pembelajaran di kelas.

Gambar 1. Contoh Media Interaktif yang digunakan di SDN Pelambuan 7 Banjarmasin

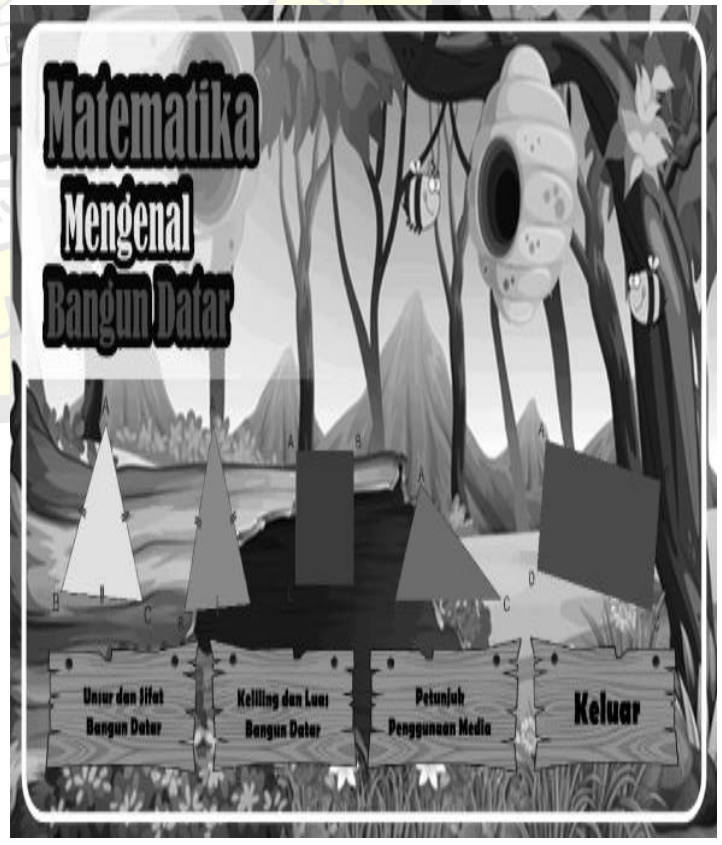


Gambar 2. Contoh Materi Mengenal Bangun Datar yang digunakan di SDN Pelambuan 7 Banjarmasin

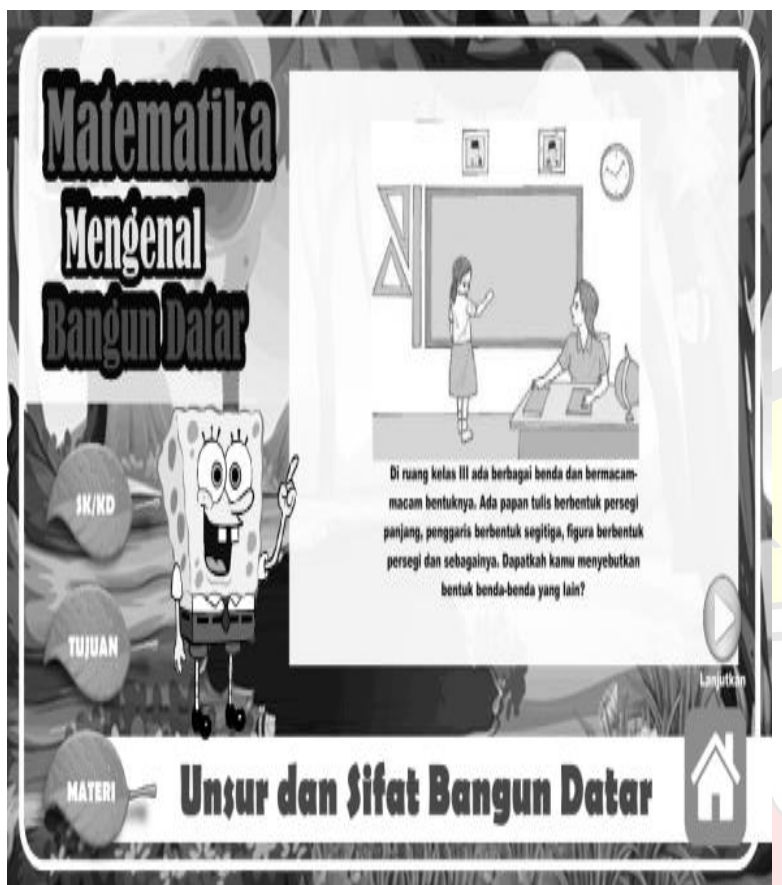

Gambar 3. Materi Buku Ajar Siswa yang sudah dikembangkan
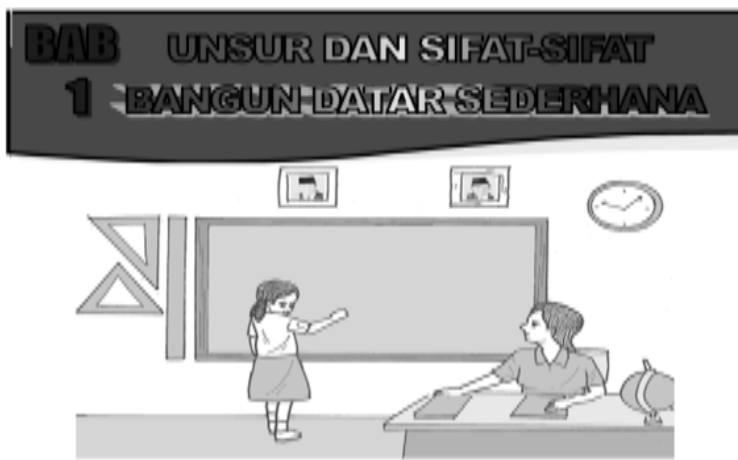

Di ruang kelas III ada berbagai benda dan bermacammacam bentuknya. Adapapan tulisberbentuk persegi panjang penggaris berbentuk segitiga, figura berbentuk persegi dan sebagainya. Dapatkah kamu menyebutkan bentuk bendabenda yang lain?

\section{A. SIANDAII KOMIEEIENSI}

4. Memahamt unsur dan sifat-sifat bantun datar sederhana

B. KOMIZIENEI DASAII

Memgidentinkast berbaggat bangun datar sederhana menurut sifat atau unsurnya

C. TUJUAN PEMHELAJARAN

Setelah mempelajari bab ini. Kamu diharapkan dapat menyebutkan sifat-sifat segitiga, persegi dan persegi panjang.
Buku ajar siswa yang dikembangkan telah melalui serangkaian penilaian untuk mendapatkan kriteria valid, praktis dan efektif. Berdasarkan penilaian validator, maka buku ajar siswa yang dihasilkan telah memenuhi kriteria valid. Berdasarkan pelaksanaan uji coba produk di kelas III SDN Pelambuan 7 Banjarmasin.

\section{Pembahasan}

Bahan ajar itu dikatakan valid, praktis dan efektif, (Suryadi dalam Yazid, 2005, hal. 4) dapat di lihat sebagai berikut :

1. Kevalidannya jika

- Sintaks pembelajaran didukung keterlaksanaannya dengan baik oleh fungsi perangkat pembelajaran.

- Sintaks dan bahan ajar mampu menciptakan aktivitas siswa dan guru dengan baik.

- Sintaks dan bahan ajar mampu menciptakan sistem sosial dengan baik.

- Sintaks dan bahan ajar mampu menimbulkan dampak instruksional dan dampak pengiring.

2. Kepraktisannya jika :

- Sintaks pembelajaran dapat dilaksanakan dengan baik.

- Sistem sosial dapat diciptakan.

- Prinsip rekasi dapat dibangun dampak pengiring dan dampak instruksional dapat ditumbuhkan.

- Siswa dan guru dapat melaksanakan kegiatan/aktivitas sesuai dengan aktivitas yang dicantumkan pada sintaks pembelajaran.

- Guru dapat mengelola pembelajaran dan menjalankan perannya dengan baik. 
- Guru dapat menjalankan perannya sebagai motivator, fasilitator, pencetus ide.

3. Keefektifannya jika :

- Rata-rata aktivitas siswa, aktif.

- Rata-rata aktivitas siswa pada tugas, aktif.

- Rata-rata keefektifan relatif penguasaan bahan pembelajaran, efektif.

- Respons siswa terhadap pembelajaran yang dilaksanakan baik/positif.

- Respon guru terhadap pembelajaran yang dilaksanakan baik/positif.

Pada penelitian ini :

- Validasi oleh pakar dan teman sejawat berisikan validasi content, konstruk dan bahasa.

- Kepraktisan berarti dapat diterapkan oleh guru sesuai dengan yang direncanakan dan mudah digunakan oleh siswa.

Keefektifan dilihat dari potensial efek yang berupa kualitas hasil belajar, sikap dan motivasi peserta didik.

\section{Simpulan dan Saran}

\section{Simpulan}

Buku ajar siswa yang dikembangkan telah melalui serangkaian penilaian untuk mendapatkan kriteria valid, praktis dan efektif. Berdasarkan penilaian validator, maka buku ajar siswa yang dihasilkan telah memenuhi kriteria valid. Berdasarkan pelaksanaan uji coba produk di kelas III SDN Pelambuan 7 Banjarmasin, maka buku ajar siswa telah memenuhi kriteria praktis dan efektif. Secara umum dapat ditetapkan bahwa buku ajar siswa yang dihasilkan telah memenuhi kriteria kualitas produk pengembangan yang ditetapkan oleh Nieveen (1999, hal. 12), yaitu valid, praktis dan efektif.

\section{Saran}

Guru dapat menggunakan media dan buku ajar yang tepat sesuai dengan perkembangan peserta didik untuk meningkatkan minat dan motivasi belajar. Salah satunya dapat menggunakan media dan buku ajar berbasis meaningful learning ini. Selanjutnya guru maupun peneliti lainnya juga kiranya dapat membuat dan mengembangkan media dan buku ajar pada materi lainnya, dimana pengembangan media dan buku ajar pada penelitian ini hanya terbatas pada materi bangun datar untuk siswa kelas III sekolah dasar.

\section{Daftar Pustaka}

Akker, J.V. (1999). Principles and Methods of Development Research. Dodrecht: Kluwe Academic Publisher.

Ausubel, D.P. (1968). Educational Psychology a Cognitive View. New York: Holt Rinehart and Winston.

Dahar, R. W. (1988). Teori-teori belajar. Jakarta: Erlangga.

Depdiknas. (2008). Panduan Pengembangan Bahan Ajar. Direktorat Jenderal Manajemen Pendidikan Dasar dan Menengah. Jakarta: BNSP.

Hobri. (2010). Metodologi Penelitian Pengembangan (Aplikasi Pada Penelitian Pendidikan Matematika). Jember: Pena Salsabila.

Nieveen, N. (1999). Prototyping to reach product quality. Dalam J. Van Den Akker, et al (Eds.), Design approaches 
and tools in education and training. London, UK: Kluwer Academic Publisaher.

Normalasarie. (2017) Pembelajaran Kooperatif Tipe Think Pair Share (TPS) menggunakan alat peraga untuk Meningkatkan Motivasi dan Hasil Belajar Siswa. Banjarmasin. Jurnal Math Didactic

(http://jurnal.stkipbjm.ac.id/index.php/m ath/article/view/140).

Puslitjaknov. (2008). Metode Penelitian dan pengembangan. Jakarta: Depdiknas.

Yazid. A. (2011). Kevalidan, Kepraktisan, dan Efek Potensial Suatu Bahan Ajar. Diakses tanggal 30 Nopember 2018 dari http://aisyahyazid,blogspot.com/2011/12 /kevalidan-kepraktisan-dan-efel.html. 